\title{
SEJARAH PEMIKIRAN EKONOMI ISLAM
}

\section{TEORI EKONOMI DAVID RICARDO, THOMAS ROBERT MALTHUS, DAN JEAN BAPTISTE SAY}

\author{
St. Nurul Ilmi Al Fauziah 90100118113
}

\section{A. David Ricardo}

David Ricardo adalah anak ketiga dari 23 bersaudara dari keluarga Yahudi yang bernama Abraham Israel Ricardo yang bekerja sebagai seorang pialang, Ia lahir di London pada tahun 1772. Di usia ke 42, David menjadi seorang pengusaha sukses dan menjadi tuan tanah perkebunan yang sangat luas yang bernama Gatcomb Park di Gloucestershire. David tertarik dengan ilmu ekonomi dimulai sejak 1799, ketika dia tinggal di Bath saat dia memulai membaca The Wealth of Nation Adam Smith. Pada tahun 1817 dia mempublikasikan buku karya yang berjudul "On the Principle of Political Economy and Taxation".

David Ricardo merupakan seorang tokoh aliran klasik yang menyatakan bahwa nilai penukaran ada jikalau barang tersebut memiliki nilai kegunaan. Oleh karena itu, sesuatu barang dapat ditukarkan apabila barang tersebut dapat digunakan. Seseorang akan membuat sesuatu barang, karena barang itu memiliki nilai guna yang dibutuhkan oleh orang. ${ }^{2}$

Teori perdagangan internasional diketengahkan oleh David Ricardo yang mulai dengan anggapan bahwa lalu lintas pertukaran internasional hanya berlaku antara dua Negara, yang diantara mereka tidak ada tembok pabean, serta kedua negara tersebut hanya beredar uang emas. Ricardo juga memanfaatkan hukum pemasaran bersama dengan teori kuantitas uang untuk mengembangkan teori perdagangan internasional. Meskipun suatu negara memiliki keunggulan absolut,

${ }^{1}$ Ubaid Al Faruq. Edi Mulyanto, Sejarah Teori-Teori Ekonomi (Banten: Unpam Press, 2017), Hal . 78-79.

${ }^{2}$ Bambang Hermanto. Mas Rasmini, Konsep Sistem Ekonomi Indonesi, Modul 2: Konsep Dan Praktik Bisnis Di Indonesia Vol. 2 No. 1, 2019, Hal. 6. 
tetapi apabila dilakukan perdagangan tetap akan menguntungkan bagi kedua negara yang melakukan perdagangan. ${ }^{3}$

Menurutnya perdagangan internasional yang seimbang dan berkeadilan akan terwujud jika masing-masing negara menekankan pada dimensi keunggulan komparatif. Hal ini bermakna bahwa negara-negara yang menghasilkan produk tertentu dengan biaya relatif rendah akan memiliki keunggulan atas produk tersebut dalam perdagangan internasional. Melalui cara ini akan terjadi efisiensi di mana setiap negara akan berpartisipasi dalam aktifitas perdagangan internasional sesuai dengan kemampuan terbaiknya dalam produk-produk tertentu. ${ }^{4}$

\section{B. Tomas Malthus}

Malthus lahir pada tanggal 13 februari 1766 di Surrey, Inggris. Thomas Robert merupakan nama yang Ia dapatkan saat dibaptis sehingga dia lebih dikenal dengan sebutan Thomas Malthus. Pada tahun 1784 Malthus masuk ke Universitas Cambridge menempuh pendidikan di jurusan matematika dan bahasa. Pada tahun 1805 Malthus diangkat menjadi profesor sejarah modern dan ekonomi politik di perguruan tinggi East India Company College di Haileyburry. Ia meninggal pada 29 Desember 1834 dikarenakan serangan jantung. Beberapa karya Malthus yang terkenal adalah bukunya yang berjudul Essay on Population yang dicetak pertama kali pada tahun 1978, dan dicetak hingga pada cetakan ke-enam. ${ }^{5}$

Istilah krisis selalu dikaitkan dengan tidak seimbangnya antara supply (ketersediaan) dengan demand (kebutuhan), yaitu ketika angka kebutuhan lebih tinggi dari ketersediaan, maka terjadilah krisis. Kekhawatiran terhadap krisis

${ }^{3}$ Zulkifli, Kontribusi Investasi Dan Ekspor Terhadap Pertumbuhan Ekonomi Di Provinsi Sulawesi Selatan, Ecces (Economics, Social, And Development Studies), Vol. 4 No. 2, Hal.8.

4 Mohammad Maiwan, Teori-Teori Ekonomi Politik Internasional Dalam Perbincangan: Aliran Dan Pandangan. J. Ilm. Mimb. Demokr, Vol. 15, 2015, Hal 111

${ }^{5}$ Ubaid Al Faruq. Edi Mulyanto, Sejarah Teori-Teori Ekonomi (Banten: Unpam Press, 2017), Hal. 88 
pangan pertama dinyatakan oleh Thomas Robert Malthus (1766-1834), bahwa laju pertambahan penduduk meningkat berdasarkan deret ukur, sedangkan produksi pangan berdasar deret hitung. ${ }^{6}$ Malthus merumuskan sebuah konsep tentang pertambahan hasil yang semakin berkurang (diminishing returns) yang menggambarkan bahwa jumlah populasi di suatu negara akan sangat cepat pada deret ukur (pelipatgandaan: 1, 2, 4, 8,.dan seterusnya) sedangkan persediaan pangan hanya meningkat menurut deret hitung $(1,2,3,4,5$, dan seterusnya) karena lahan yang dimiliki keluarga semakin sempit, maka kontribusi marjinalnya terhadap total total produksi pangan juga menurun dan pendapatan juga menurun sampai pada level sedikit diatas subsisten. ${ }^{7}$

Teori Malthus berlaku sebelum Perang Dunia Kedua dimana untuk pengendalian penduduk sebagaimana dikemukakan Malthus dapat dilakukan dengan positive checks yakni melalui proses kematian seperti adanya berbagai penyakit dan epidemik, bencana alam, kelaparan, kekurangan pangan dan perang. Pasca Perang Dunia teori Malthus tidak relevan lagi dengan kondisi lapangan karena tidak cocok dengan bukti lapangan, yakni data empiris. Oleh karena itu, akhirnya teori Malthus dikoreksi dan koreksinya adalah bukan positive checks yang diperlukan untuk pengendalian penduduk, melainkan pembangunan. ${ }^{8}$

\section{Jean Baptiste Say}

J. B. Say adalah tokoh ekonomi penting Prancis yang lahir di Lyon, Prancis pada tahun 1767 tepat sembilan tahun sebelum The Wealth of Nation dicetak. Say berasal dari keluarga protestan di Prancis selatan yang pindah ke

${ }^{6}$ Titin Izzatul Muna, Mohammad Nurul Qomar, Relevansi Teori Scarcity Robert Malthus Dalam Perspektif Ekonomi Syariah, SERAMBI: Jurnal Ekonomi Manajemen Dan Bisnis Islam, Vol. 2 No. 1, 2020, Hal. 3.

${ }^{7}$ Tafeta Febryani S. Sri Kusreni, Determinan Pertumbuhan Ekonomi Di 4 Negara ASEAN. Jurnal Ilmu Ekonomi Terapan, Vol. 2 No. 1, 2017, Hal 5

${ }^{8}$ Lalu Muh. Kabul, Manajemen Pembangunan Kependudukan: Koreksi Terhadap Teori Malthus. Ganec Swara, Vol. 13 No. 2, 2019, Hal. 324. 
Jenewa dan kemudian menetap di Paris. ${ }^{9}$ Say sangat memuja Adam Smith, ia berjasa dalam melakukan kodifikasi pemikiran Smith dan dirangkum dalam bukunya Traite d'Economie Politique pada tahun 1803, dan mendukung faham laissez faire. ${ }^{10}$

Jean Baptiste Say mempopulerkan hukum J.B.Say's yang berbunyi "supply creates its own demand". Hukum ini memiliki makna bahwa setiap barang dan jasa yang diproduksi akan mencipatakan permintaannya sendiri. Artinya produksi barang dan jasa memiliki hubungan positif dengan permintaan barang dan jasa tersebut. ${ }^{11}$

Rumus Hukum Say, bahwa penawaran barang (X) menciptakan permintaan untuk (Y). Asumsinya, bahwa nilai produksi selalu sama dengan pendapatan. Dengan demikian, dalam keadaan seimbang, produksi cenderung menciptakan permintaannya sendiri. Ilustrasi Say jika dikaitkan dengan ekonomi nelayan mengatakan bahwa semakin besar tangkapan ikan dan variasi ikan (produksi) yang diperoleh, maka semakin besar jumlah pembelian yang dilakukan oleh pembeli (pasar), begitu juga sebaliknya. ${ }^{12}$

${ }^{9}$ Ubaid Al Faruq. Edi Mulyanto, Sejarah Teori-Teori Ekonomi (Banten: Unpam Press, 2017), Hal. 72.

${ }^{10}$ Hastarini Dwi Atmanti, Kajian Teori Pemikiran Ekonomi Mazhab Klasik Dan Relevansinya Pada Perekonomian Indonesia, JEB17: Jurnal Ekonomi Dan Bisnis, Vol. 2 No. 2, 2017, Hal. 516.

11 Dudi Septiadia. Umbu Joka, Analisis Respon Dan Faktor-Faktor Yang Mempengaruhi Permintaan Beras Indonesia AGRIMOR, Vol. 4 No. 3, 2019, Hal. 43.

${ }^{12}$ M Syaiful Suib. Halimatus Sakdiyah, Tantangan Nelayan Dalam Menghadapi Era Globalisasi Ekonomi Perspektif Ekonomi Islam (Studi Di Desa Sumberanyar Kec. Paiton Probolinggo), PROFIT: Jurnal Kajian Ekonomi Dan Perbankan Syariah, Vol.3 No. 1, 2019, Hal. 60. 


\section{DAFTAR PUSTAKA}

Atmanti, H. D. (2017). Kajian Teori Pemikiran Ekonomi Mazhab Klasik dan Relevansinya pada Perekonomian Indonesia. JEB17: Jurnal Ekonomi dan Bisnis, 2(02).

Maiwan, M. (2015). Teori-Teori Ekonomi Politik Internasional Dalam Perbincangan: Aliran Dan Pandangan. J. Ilm. Mimb. Demokr., 15, 109-25.

Faruq, U. A., \& Mulyanto, E. (2017). Sejarah Teori-Teori Ekonomi.

Muna, T. I., \& Qomar, M. N. (2020). Relevansi Teori Scarcity Robert Malthus Dalam Perspektif Ekonomi Syariah. SERAMBI: Jurnal Ekonomi Manajemen dan Bisnis Islam, 2(1), 1-14.

KABUL, L. M. (2019). Manajemen Pembangunan Kependudukan: Koreksi Terhadap Teori Malthus. Ganec Swara, 13(2), 317-325.

Febryani, T. (2017). Determinan Pertumbuhan Ekonomi di 4 Negara ASEAN. Jurnal Ilmu Ekonomi Terapan, 2(1).

Hermanto, H. B., \& Mas Rasmini, S. E. (2019). Konsep Sistem Ekonomi Indonesia. MODUL 2: KONSEP DAN PRAKTIK BISNIS DI INDONESIA 2.1 .

Zulkifli, Z. (2017). Kontribusi Investasi dan Ekspor Terhadap Pertumbuhan Ekonomi Di Provinsi Sulawesi Selatan. EcceS (Economics, Social, and Development Studies), 4(2), 163-180.

Septiadi, D., \& Joka, U. (2019). Analisis Respon dan Faktor-Faktor yang Mempengaruhi Permintaan Beras Indonesia. AGRIMOR, 4(3), 42-44.

Suib, M. S. (2019). Tantangan Nelayan dalam Menghadapi Era Globalisasi Ekonomi Perspektif Ekonomi Islam (Studi di Desa Sumberanyar Kec. Paiton Probolinggo). PROFIT: Jurnal Kajian Ekonomi dan Perbankan Syariah, 3(1), 52-70. 